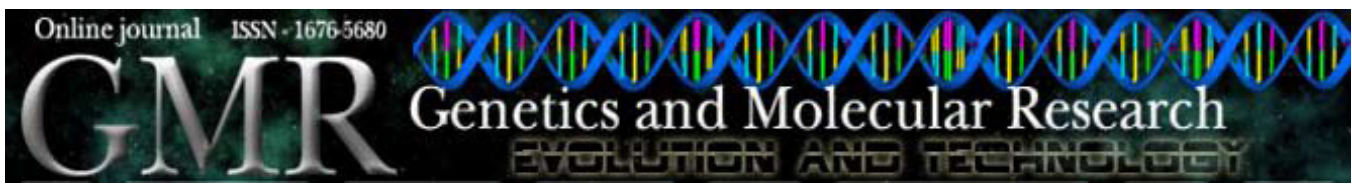

\title{
Genetic relationships among and within wild and cultivated olives based on RAPDs
}

\author{
M. Sesli ${ }^{1}$ and E.D. Yeğenoğllu ${ }^{2}$ \\ ${ }^{1}$ College of Tobacco Expertise, Turkish Republic, Celal Bayar University, \\ Akhisar, Manisa, Turkey \\ ${ }^{2}$ Akhisar Vocational College, Turkish Republic, Celal Bayar University, \\ Akhisar, Manisa, Turkey
}

Corresponding author: M. Sesli

E-mail: meltem.sesli@bayar.edu.tr

Genet. Mol. Res. 9 (3): 1550-1556 (2010)

Received May 1, 2010

Accepted June 26, 2010

Published August 10, 2010

DOI 10.4238/vol9-3gmr866

\begin{abstract}
We examined genetic relationships among wild and cultivated olives, which is a very important crop in the economy of the Aegean region. We used RAPD analysis to evaluate relationships among and within 22 olive subspecies from Manisa, Mugla and Izmir provinces in Turkey. Twelve of the subspecies were wild and 10 were cultivated olives. Fifty-two primers were used (OP-Q 1-20, OP-I 1-20, OP-F 14-15-16-17, and OP-K 1-8) and 49 polymorphic bands were selected and used for analysis. The dendrogram based on unweighted pair-group cluster analysis using the SorensenDice coefficient of similarity index indicated two major groups, dividing wild olives from cultivated olives. The patterns of genetic relationships among and within the different olives were analyzed by means of analysis of molecular variance. We found significant differences between wild and cultivated olives $\left(\Phi_{\text {st }}=0.1507 ; \mathrm{P}<\right.$ 0.001). In order to determine the genetic relationship among wild and cultivated olives, principal coordinate analysis was used to examine the variation among subspecies. The wild and cultivated
\end{abstract}


olives formed two main groups, one on the right side and the other on the left side of the principal coordinates graph, respectively. This was compatible with the results we obtained from analysis of molecular variance.

Key words: Wild and cultivated olives; Principal coordinate analysis; Random amplified polymorphic DNA; Genetic relationships;

AMOVA; Dice

\section{INTRODUCTION}

Olives, whose homeland is Anatolia, has a huge variety in Turkey. It is cultivated along the coastline, which is under the influence of the warm Mediterranean climate. There are two subspecies of olives grown in the Aegean, Marmara, Black Sea, and Southeast Anatolia regions, namely wild and cultivated olives (MOARA, 1991). It is very important to know the genetic subspecies of olives, which have a huge significance in terms of the region's economy, and to grow them efficiently. In this respect, random amplified polymorphic DNA (RAPD) is used providing dominant markers in determining the genetic relationship among wild and cultivated olives (Belaj et al., 2002; Martins-Lopes et al., 2009).

Cluster analysis is performed using some matrices in the determination of genetic relationships among plants. One of the similarity/distance metrics used in software clustering is Sorensen-Dice (association coefficient) (Dice, 1945; Sorensen, 1948). This metric is used to calculate the similarity between two objects. Similarity is the inverse of distance, and the greater the distance between two objects, the less similar they are (Saeed et al., 2003).

Genetic distances between plants were calculated by applying the Euclidean metric of Excoffier et al. (1992). AMOVA (analysis of molecular variance) estimates genetic structure or the degree of differentiation among and within populations (Wallace, 2003), for example, the populations being defined on breeding criteria. AMOVA was performed to study the effect of population classification criteria. Belaj et al. (2002) used AMOVA to determine the genetic variation among olive varieties cultivated in the west, center and east of the Mediterranean region.

PCO (principal coordinate analysis) is used for the purpose of revealing the genetic similarity among plants. For instance, Baldoni et al. (2006) used this analytical method to exhibit the relationship among wild and cultivated olive cultivars.

The aim of this study was to determine the genetic relationships among wild and cultivated olives with different analytical methods using RAPD markers.

\section{MATERIAL AND METHODS}

\section{Plant material}

A total of 22 olives were used, including 12 wild and 10 cultivated olives obtained from the Aegean region. Table 1 shows the places from which these olives were supplied. 


\begin{tabular}{|c|c|c|}
\hline Type of olive & Origin & Aegean region (Province) \\
\hline Wild 1 & Pinarcik & Muğla, Milas, Turkey \\
\hline Wild 2 & Pinarcik & Muğla, Milas, Turkey \\
\hline Wild 3 & Caglak & Akhisar, Manisa, Turkey \\
\hline Wild 4 & Sabancilar & Akhisar, Manisa, Turkey \\
\hline Wild 5 & Caglak & Akhisar, Manisa, Turkey \\
\hline Wild 6 & Sabancilar & Akhisar, Manisa, Turkey \\
\hline Wild 7 & Bornova & Izmir, ORI, Turkey \\
\hline Wild 8 & Harlak & Akhisar, Manisa, Turkey \\
\hline Wild 9 & Bornova & Izmir, ORI, Turkey \\
\hline Wild 10 & Bademli & Dikili, Izmir, Turkey \\
\hline Wild 11 & Karacakas & Soma, Manisa, Turkey \\
\hline Wild 12 & Yayakırıldık & Akhisar, Manisa, Turkey \\
\hline Gemlik 2 & Akhisar & Akhisar, Manisa, Turkey \\
\hline Manzanilla 3 & Bornova & Izmir, ORI, Turkey \\
\hline Gemlik 3 & Bornova & Izmir, ORI, Turkey \\
\hline Manzanilla 1 & Bornova & Izmir, ORI, Turkey \\
\hline Gemlik 4 & Bornova & Izmir, ORI, Turkey \\
\hline Manzanilla 2 & Bornova & Izmir, ORI, Turkey \\
\hline Domat & Bornova & Izmir, ORI, Turkey \\
\hline Uslu & Akhisar & Akhisar, Manisa, Turkey \\
\hline Edremit & Akhisar & Akhisar, Manisa, Turkey \\
\hline Memecik & Bornova & Izmir, ORI, Turkey \\
\hline
\end{tabular}

ORI = Olive Research Institute of Turkey.

\section{DNA extraction}

Genomic DNA was extracted from young leaves using the Doyle and Doyle method (1987). Pre-chilled mortar and pestle was used to ground fresh leave tissues. Powdered tissues were immediately transferred to $1.5-\mathrm{mL}$ Eppendorf tubes. A volume of $700 \mu \mathrm{L}$ preheated CTAB extraction buffer ( $2 \%$ CTAB, $20 \mathrm{mM}$ EDTA, $1.4 \mathrm{M} \mathrm{NaCl}, 100 \mathrm{mM}$ Tris$\mathrm{HCl}, \mathrm{pH} 8.0,2 \% \beta$-mercaptoethanol) was added to frozen ground leaves, mixing several times by gentle inversion. Samples with CTAB buffer were incubated for $30 \mathrm{~min}$ at $65^{\circ} \mathrm{C}$. Tubes were mixed by inversion every 5 min during the incubation time. After removing from the hot bath, tubes were cooled down, and then, $700 \mu \mathrm{L}$ cold chloroform:isoamyl alcohol (24:1) was added. Tubes were centrifuged at $10,000 \mathrm{rpm} / \mathrm{min}$ for $10 \mathrm{~min}$ at $4^{\circ} \mathrm{C}$. Supernatants were transferred to new tubes; $600 \mu \mathrm{L}$ cold chloroform:isoamyl alcohol (24:1) was added and the tubes were mixed by gentle inversion for $5 \mathrm{~min}$. Samples were centrifuged at $10,000 \mathrm{rpm} / \mathrm{min}$ for $10 \mathrm{~min}$ at $4^{\circ} \mathrm{C}$. Supernatants were transferred to fresh tubes including $10 \mathrm{M}$ ammonium acetate and $3 \mathrm{M}$ sodium acetate. A volume of $500 \mu \mathrm{L}$ cold isopropanol was added, followed by very gentle shaking for DNA precipitation. Precipitated DNA was removed with a pipette, and washed with $70 \%$ ethanol. DNA was dried and resuspended in $50 \mu \mathrm{L}$ EDTA. The crude DNA sample was treated with $1 \mathrm{~mL}$ RNAase $\left(10 \mathrm{mg} / \mathrm{mL}\right.$ stock) for $10 \mathrm{~min}$ at $37^{\circ} \mathrm{C}$.

\section{Spectrophotometric analysis}

DNA quality and concentration in samples were determined by both spectrophotometric analysis and electrophoresis on $0.8 \%$ agarose gels. In the spectrophotometric analysis, the optical density of each sample of DNA was determined at 230, 260 and $280 \mathrm{~nm}$. 
Optical density ratios were evaluated and only good-quality DNA samples were used in polymerase chain reaction (PCR) (Wu et al., 2004).

\section{RAPD-PCR analysis}

Fifty-two primers from the kits OP-Q 1-20, OP-I 1-20, OP-F 14-15-16-17, OP-K 1-8 (Operon Technologies, Alameda, CA, USA) were used for RAPD-PCR analysis. PCR was performed in an Eppendorf MasterCycler Thermal Cycler in a total volume of $25 \mu \mathrm{L}$. The PCR mixture included $25 \mathrm{ng}$ template DNA, $2.42 \mu \mathrm{L}$ 10X PCR buffer (with $\mathrm{MgCl}_{2}$; Sigma), $0.44 \mu \mathrm{L}$ dNTP (Sig$\mathrm{ma}$ ), $1 \mu \mathrm{M}$ primer, and $0.13 \mu \mathrm{L}$ Taq DNA polymerase (Sigma). The amplification reactions were carried out for $60 \mathrm{~s}$ at $94^{\circ} \mathrm{C}$ as an initial denaturation. The PCR program comprised 35 cycles for $20 \mathrm{~s}$ at $94^{\circ} \mathrm{C}, 20 \mathrm{~s}$ at $35^{\circ} \mathrm{C}$, and $30 \mathrm{~s}$ at $72^{\circ} \mathrm{C}$, and a final extension was performed at $72^{\circ} \mathrm{C}$ for $5 \mathrm{~min}$.

\section{Agarose gel electrophoresis}

Amplification products were loaded onto $1.5 \%$ agarose gels (Sigma) in $0.5 \mathrm{X}$ TBE buffer with $0.5 \mu \mathrm{g} / \mathrm{mL}$ ethidium bromide, and electrophoresed at $100 \mathrm{~V}$ constant voltage. For evaluating the base pair length of bands, a DNA ladder (Sigma, Fermentas) was loaded on the first lane of each gel. After the separation of PCR products by agarose gel electrophoresis, gels were visualized with the Photo Print (Vilber Lourmat, France) imaging system and analyzed by the BioOne $\mathrm{D}++$ software (Vilber Lourmat). The RAPD bands were scored as 1 for present or 0 for absent and only clear bands were scored for the construction of the data matrix. The dendrogram was constructed using NTSYS-pc 2.01 (Rohlf, 1998) according to the Sorensen-Dice coefficient of similarity (Dice, 1945; Sorensen, 1948), and the UPGMA algorithm (unweighted pair-group method using arithmetic averages) was chosen as the hierarchical clustering analysis method.

AMOVA (Excoffier, 1992) was carried out on the RAPD data using Arlequin 3.11 with 1000 permutations (Excoffier et al., 2005), and PCO analysis was performed by FAMD version 1.23 (Schlüter and Harris, 2006).

\section{RESULTS}

Thirty of 52 primers, which were used to determine the genetic relationship between wild and cultivated olives, yielded scorable bands and, after selection, 49 polymorphic bands were used. In accordance with the Sorensen-Dice similarity index, the closest samples among the wild olives based on their genetic similarities are wilds 6 and 7 with 0.63 . In the cluster in which wild olives were included, the other samples closest to each other based on their genetic similarities are wilds 1 and 2 and wilds 3 and 4 with 0.57 , and wilds 10 and 11 with 0.50 .

The closest samples among the cultivated olives based on their genetic similarities are Gemlik 3 and Manzanilla 1 with 0.53 . In the cluster in which cultivated olives were included, the other samples closest to each other based on their genetic similarities are Gemlik 4 and Manzanilla 2 with 0.50 and Edremit and Memecik with 0.44 .

When UPGMA is applied with regard to the Sorensen-Dice similarity index, as shown in Figure 1, the formation of two main groups of cluster is evident. It is observed that wild olives cluster in the first group and cultivated olives cluster in the second group. This shows us that olive subspecies form groups based on their growth conditions. 


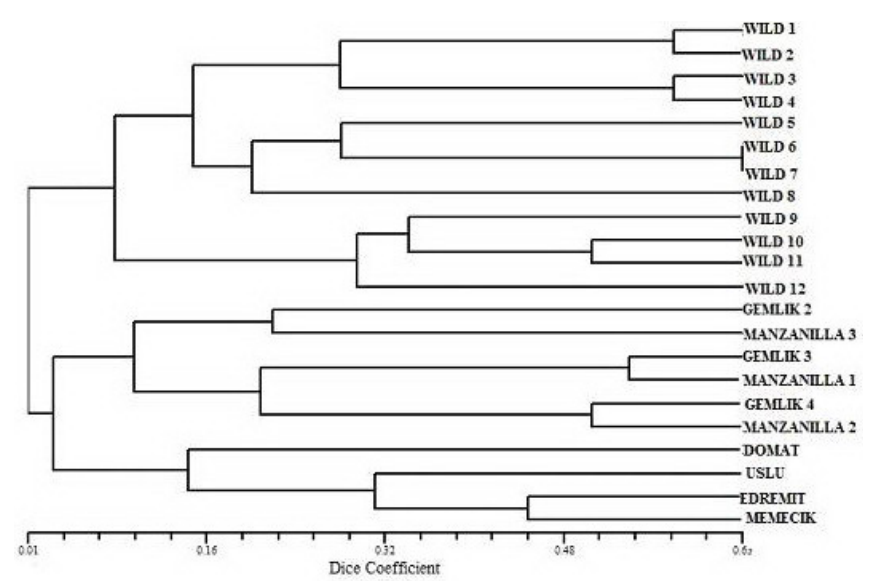

Figure 1. UPGMA dendrogram based on the Sorensen-Dice similarity index.

Genetic distance was measured by looking at the variance among and within the olives in accordance with the growth conditions using AMOVA (wild and cultivated). The results in Table 2 were obtained accordingly. As seen in table, the proportion of total diversity found within populations was $84.93 \%$ and differences between wild and cultivated olives were significant $\left(\Phi_{\text {st }}=0.1507 ; \mathrm{P}<0.001\right)$.

Table 2. Analysis of molecular variance of wild and cultivated olives.

\begin{tabular}{lcccc}
\hline Source of variation & d.f. & Variance components & Total variance (\%) & $\Phi_{\text {st }}$ \\
\hline Among populations & 1 & 0.8318 & $15.07 \%$ & 0.1507 \\
Within populations & 20 & 4.6872 & $84.93 \%$ & $<0.001$ \\
Total & 21 & 5.5193 & & \\
\hline
\end{tabular}

d.f. $=$ degrees of freedom.

Another method used for determining the genetic relationship among wild and cultivated olives is PCO. The genetic similarity between individuals was determined with this analysis. Figure 2 shows the graph formed based on the RAPD data of wild and cultivated olives.

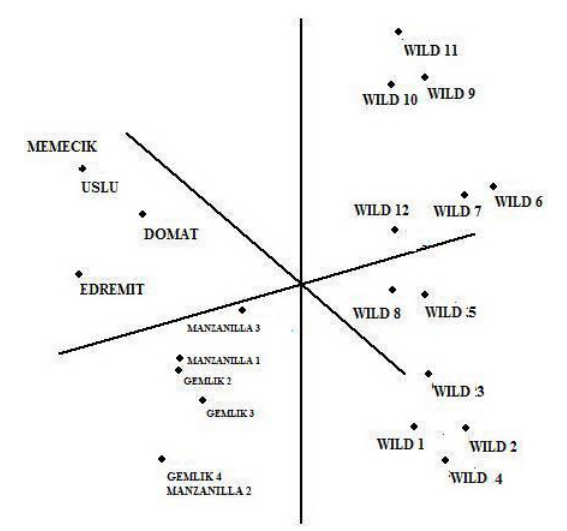

Figure 2. Principal coordinate analysis of RAPD data for wild and cultivated olives. 
In accordance with the results obtained from the PCO analysis, olives were plotted on principal coordinates 1,2 and 3, accounting for $19.43,12.56$ and $11.45 \%$ of variation, respectively, and together explaining $43.44 \%$ of total variation. When the graph is examined, it is observed that two different main groups are formed. A group covering all the wild olives is observed on the right side of the graph, and another group covering the cultivated olives is observed on the left side of the graph. This shows us that there is a significant difference between wild and cultivated olives.

\section{DISCUSSION}

We examined genetic relationships among olive subspecies and found that wild and cultivated olives form two main groups based on UPGMA. AMOVA and PCO showed that their growth conditions affected the genetic relationship among them because wild olives are formed spontaneously or through the seeds of cultivated olives spread around. Cultivated olives, on the other hand, are mostly produced through the vegetative method (Mendilcioglu, 1999). In this case, as Lumaret et al. (2004) mentioned in their study, heterozygosity in wild olives is higher than in cultivated olives. Thus, it is expected that genetic similarities of wild and cultivated olives are distant.

It is important to show that the similarities between wild 6 and wild 7 olives were found to be the closest samples in our study, because wild 6 was obtained from Akhisar and wild 7 was obtained from ORI, Bornova. There is a distance of $90 \mathrm{~km}$ between Akhisar and Izmir; thus, such genetic closeness is a finding showing that gene flow may occur as a result of various factors such as birds, animals, etc., spreading olive seeds (Alcántara et al., 1997; Spennemann and Allen, 2000).

In conclusion, determining the genetic relationships among wild and cultivated olives grown in the Aegean region is valuable in the sense that olives, being a significant source of income, contribute greatly to the economy of our country. In this respect, production considering growth conditions would make important contributions to quality and efficiency.

\section{ACKNOWLEDGMENTS}

Research supported by the Turkish Republic State Planning Organization.

\section{REFERENCES}

Alcántara JM, Rey PJ, Valera F, Sánchez-Lafuente AM, et al. (1997). Habitat alteration and plant intra-specific competition for seed dispersers. An example with Olea europaea var. sylvestris. Oikos 79: 291-300.

Baldoni L, Tosti N, Ricciolini C, Belaj A, et al. (2006). Genetic structure of wild and cultivated olives in the central Mediterranean basin. Ann. Bot. 98: 935-942.

Belaj A, Satovic Z, Rallo L and Trujillo I (2002). Genetic diversity and relationships in olive (Olea europaea L.) germplasm collections as determined by randomly amplified polymorphic DNA. Theor. Appl. Genet. 105: 638-644.

Dice LR (1945). Measures of the amount of ecologic association between species. Ecology 26: 297-302.

Doyle JJ and Doyle JL (1987). A rapid DNA isolation procedure for small quantities of fresh leaf tissue. Phytochem. Bull. 19: 11-15.

Excoffier L (1992). WinAMOVA Version 1.55. Analysis of Molecular Variance, Graphical Windows 3.x Program for the Analysis of Population Structure from Molecular or Conventional Genetic Data. Available at [http://cmpg.unibe.ch/ excoffier/]. Accessed February 2010. 
Excoffier L, Smouse P and Quattro J (1992). Analysis of molecular variance inferred from metric distances among DNA haplotypes: application to human mitochondrial DNA restriction data. Genetics 131: 479-491. Available at [http:// www.genetics.org/cgi/content/abstract/131/2/479]. Accessed February 2010.

Excoffier L, Laval G and Schneider S (2005). Arlequin (version 3.0): an integrated software package for population genetics data analysis. Evol. Bioinform. Online 1: 47-50.

Lumaret R, Ouazzani N, Michaud H, Vivier G, et al. (2004). Allozyme variation of oleaster populations (wild olive tree) (Olea europaea L.) in the Mediterranean Basin. Heredity 92: 343-351.

Martins-Lopes P, Gomes S, Lima-Brito J, Lopes J, et al. (2009). Assessment of clonal genetic variability in Olea europaea L. 'Cobrançosa' by molecular markers. Sci. Hortic. 123: 82-89.

Mendilcioglu K (1999). Olive. In: Subtropical Climate Fruits. Publications of Faculty of Agriculture, Ege University, Bornova-Izmir, 8 and 30.

MOARA (Ministry of Agriculture and Rural Affairs) (1991). Standard Olive Varieties Catalogue. Ministry of Agriculture and Rural Affairs Publishing, Ankara.

Rohlf FJ (1998). NTSYSpc: Numerical Taxonomy and Multivariate Analysis System. Version 2.02. Exeter Software, Setauket.

Saeed M, Maqbool O, Babri HA, Hassan SZ, et al. (2003). Software Clustering Techniques and the Use of Combined Algorithm. In: Proceedings of the Seventh European Conference on Software Maintenance and Reengineering (CSMR'03), March 26-28. IEEE Computer Society Washington, Benevento, 301.

Schlüter PM and Harris SA (2006). Analysis of multilocus fingerprinting data sets containing missing data. Mol. Ecol. Notes 6: 569-572.

Sorensen T (1948). A method of establishing groups of equal amplitude in plant sociology based on similarity of species content and its application to analyses of the vegetation on Danish commons. K. Dan. Vidensk. Selsk. Biol. Skr. 5: 1-34.

Spennemann DHR and Allen LR (2000). Feral olives (Olea europaea) as future woody weeds in Australia: a review. Aust. J. Exp. Agric. 40: 889-901.

Wallace L (2003). Methods Available for the Analysis of Data from Dominant Molecular Markers. Department of Biology, University of South Dakota, Vermillion.

Wu SB, Collins G and Sedgley M (2004). A molecular linkage map of olive (Olea europaea L.) based on RAPD, microsatellite, and SCAR markers. Genome 47: 26-35. 